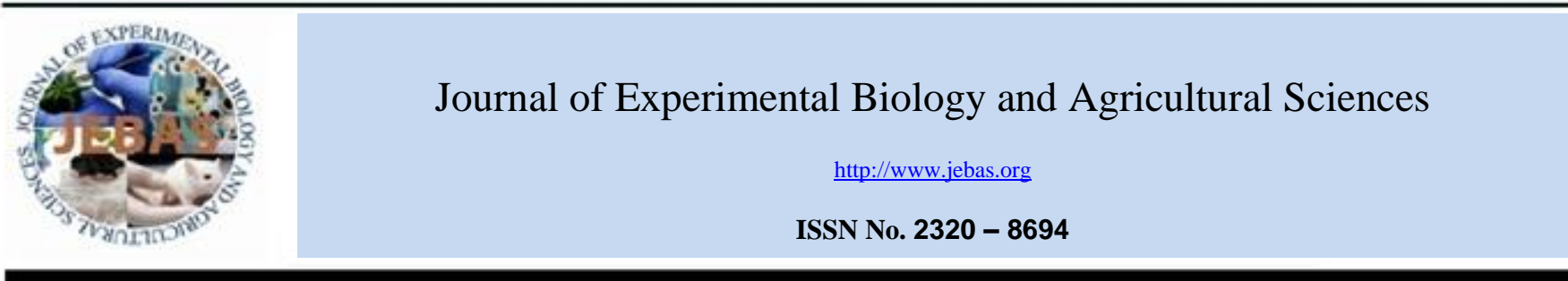

\title{
CHARACTERIZATION OF SOME INDIAN SESAME (Sesamum indicum L.) CULTIVARS THROUGH SOLUBLE SEED STORAGE PROTEIN MARKERS
}

\author{
Arna Das ${ }^{1}$, Sarita K. Pandey ${ }^{2}$, Pradipta Bhattacharya ${ }^{3}$, T. Dasgupta ${ }^{3}$ \\ ${ }^{1}$ Assistant Professor, Dept. of Genetics \& Plant Breeding, B. A. College of Agriculture, Anand Agricultural University, Anand, Gujarat, India-388001 \\ Mobile no. 9433903 523; \\ ${ }^{2}$ Special Project Scientist, International Crops Research Institute for The Semi-Arid Tropics (ICRISAT), Patancheru, Telangana, India \\ ${ }^{3}$ Department of Genetics \& Plant Breeding, Institute of Agricultural Science, University of Calcutta, 51/2 Hazra Road, Kolkata, India - 700019
}

Received - January 04, 2018; Revision - January 13, 2018; Accepted - February 19, 2018

Available Online - February 20, 2018

DOI: http://dx.doi.org/10.18006/2018.6(1).243.248

KEYWORDS
Divergence
Electrophoresis
Seed Coat Colour
Sesame
Protein polymorphism
Zone of adoption

* Corresponding author

E-mail: arna_das@hotmail.com (Arna Das)

Peer review under responsibility of Journal of Experimental Biology and Agricultural Sciences.

Production and Hosting by Horizon Publisher India [HPI] (http://www.horizonpublisherindia.in/).

All rights reserved.

\begin{abstract}
Seed storage protein markers being less sensitive to environmental fluctuation than phenological traits, has been successfully employed in assessing divergence in many crop plants. The present study was aimed to find out correlation of seed storage protein markers in twenty eight Indian sesame cultivars with their agro-ecological zone of adoption and their seed coat colour. Sodium Dodecyl Sulphate Polyacrylamide Gel Electrophoresis (SDS-PAGE) revealed altogether twenty two protein bands of which thirteen were polymorphic with varied molecular weights. Specific bands, relating to specific agro-ecologies were found. Moreover, bands of 93.40 KDa and 68.05 KDa were found associated with production of darker shades of seed coat colour. Clustering pattern based on protein similarity value offered no definite grouping, either to specific agro-ecological zones of adoption or to specific seed coat colour. It is concluded that individual protein banding pattern can be linked to agro-ecological adoption zone and seed coat colour which is helpful in divergence and phylogenetic study in sesame.
\end{abstract}

All the article published by Journal of Experimental Biology and Agricultural Sciences is licensed under a Creative Commons Attribution-NonCommercial 4.0 International License Based on a work at www.jebas.org. 


\section{Introduction}

Sesame (Sesamum indicum L.) as an oilseed is potent to meet the domestic demand of edible oil in India. Though India is one of the major sesame producers in the world (www.faostat.fao.org 2016), but this crop has been highly neglected and identified as an orphan crop. This resulted into enormous loss of germplasm and drastic reduction in variation. An insight into characterization and preservation of naturally existing variation in sesame, therefore, has become a necessity for further improvement of the crop. Phenological traits, due to pleiotropic effect and polygenic control, exhibit overlapping variation within and between species populations offering taxonomic complexity (Huber-Morath \& Phlomis, 1982; Wang et al., 2010; Pabby \& Rockman, 2013). Soluble seeds storage protein markers assessed through Sodium Dodecyl Sulphate Polyacrylamide Gel Electrophoresis (SDSPAGE) had been successfully employed to characterize cultivated varieties in several crop plant species, of which Mung (Ghaffor et al., 2002), Pea (Jha \& Ohri, 2002), Einkorn wheat (Alvarez et al., 2006), Brassica (Khurshid \& Rabbani, 2012) are few to name. Reliability of soluble seed storage protein markers lies in the fact that these are less influenced by environmental fluctuation as compared to phenological markers, therefore stable, uniform and reproducible. Moreover SDS-PAGE takes less time, is simpler to perform and is more economic than nucleic acid markers.

Only a few references are available on soluble seeds storage protein polymorphism study involving Indian sesame germplasm. Akhila \& Beevy (2011) reported the presence of fourteen bands in a study of seven sesame genotypes including wild and cultivated species. The protein polymorphism was able to group the genotypes belonging to two different species into separate clusters. Das et al. (2013) reported the presence of twenty two bands in a study with twenty six advanced sesame mutant lines and respective controls. But the study did not offer much specificity in grouping the mutants according to their parental origin. Dar et al., (2014) reported as much as twenty one bands in a study with fifty two Indian sesame germplasms. Similarly, Singharaj \& Onsaard (2015) carried out SDS-PAGE in sesame genotypes with varied seed coat colour, for its food value. According to recent study, seed coat colour in sesame is more helpful in phylogenetic study than geographic origin of genotypes (Zhang et al., 2013).

In the present research work an attempt was made to search for correlation between soluble seed storage protein polymorphism of a number of Indian sesame cultivars with the cultivars' agro-ecological zone of adoption and also with cultivars' seed coat colour, which would definitely incite more knowledge on divergence and phylogeny in sesame. Correlation of protein markers with seed coat colours would further help in assessing genotypes for those biochemical traits which are linked to particular seed coat colours (Zhang et al., 2013). Such correlation, if exists, can be employed to identify diverse and superior sesame genotypes for future crop improvement programme.

\section{Materials and methods}

Twenty eight sesame cultivars from different states in India representing varied agro-ecology had been selected for the study. The detail of the genotypes is presented in Table 1. Seeds of these cultivars were availed from the sesame germplasm collection of the Department of Genetics and Plant Breeding,

Table 1 Detail of cultivars under study

\begin{tabular}{|c|c|c|}
\hline Genotypes & Seed coat colour & State: Agro-ecological zone of adoption* \\
\hline AMRIT, NIRMALA, UMA & Pale yellow & \multirow{2}{*}{ Odisha: Sub-humid, Coastal } \\
\hline OSC-207, OSC-593 & White & \\
\hline TKG-352, TKG-22 & White & Madhya Pradesh: Semi-arid, sub-humid \\
\hline DSS-09 & White & Karnataka: Arid, Semi-arid \\
\hline TMV-4, TMV-6, VRI-1 & Brown & Tamil Nadu: Semi-arid, Coastal \\
\hline GUJARAT TIL-2 (GT-2) & White & Gujarat: Arid, Semi-arid, Coastal \\
\hline CST-2001-12 & White & \multirow{2}{*}{ Haryana, Rajasthan: Arid } \\
\hline RT-54, RT-348 & Brown & \\
\hline B-14, TilotтAмa (B-67), CUMS 3, V-1, V-15, Rama & Brown & \multirow{4}{*}{ West Bengal: Humid- per humid, Coastal } \\
\hline CUMS 9, CUMS 11 & Mixed colour ${ }^{1}$ & \\
\hline CUMS 17, NIC 8316, SAHEB & Pale yellow & \\
\hline V $-10, \mathrm{~V}-12$ & Deep Brown & \\
\hline
\end{tabular}

Journal of Experimental Biology and Agriculture Science

http://www.jebas.org 
Institute of Agricultural Science, University of Calcutta, West Bengal, India.

Soluble seed storage protein was extracted and estimated following Lowry's method (Lowry et al., 1953). SDS-PAGE (12\% separating gel and 4\% stacking gel) of those extracted protein was carried out following the method of Laemmli (1970) in a regular mini $(10 \mathrm{~cm} \times 10 \mathrm{~cm})$ vertical gel system (Biotech Laboratories, India) applying a current of $30 \mathrm{~mA}$ for run through stacking gel and a current of $50 \mathrm{~mA}$ for run through separating gel. Standard marker protein, Dalton Mark VI (Sigma, USA) was used as a control. Staining and de-staining of the gel were also carried out following the method of Laemmli (1970). The banding pattern was captured through gel documentation unit (UVP Gel Doc It) and molecular weights (MW) of observed protein bands were then estimated through the Life Sciences Software available with the gel documentation unit. A matrix was prepared by giving a score of ' 1 ' for presence and ' 0 ' for absence of a particular protein band. This was carried out for all the observed protein bands for all twenty eight genotypes. A dendrogram was prepared based on protein similarity (PS) value of the genotypes with the help of the software NTSYS pc ver 2.20 (Rohlf, 2005). Protein similarity data were generated by the program, SIMQUAL and the dendrogram was generated through SAHN program. Protein dissimilarity (PD) was estimated as 1 - PS.

\section{Results}

The SDS-PAGE banding pattern for soluble seed storage protein revealed a total of twenty two bands covering all the twenty eight genotypes as reported earlier by the authors (Das et al., 2013) in their previous study on seed storage protein polymorphism
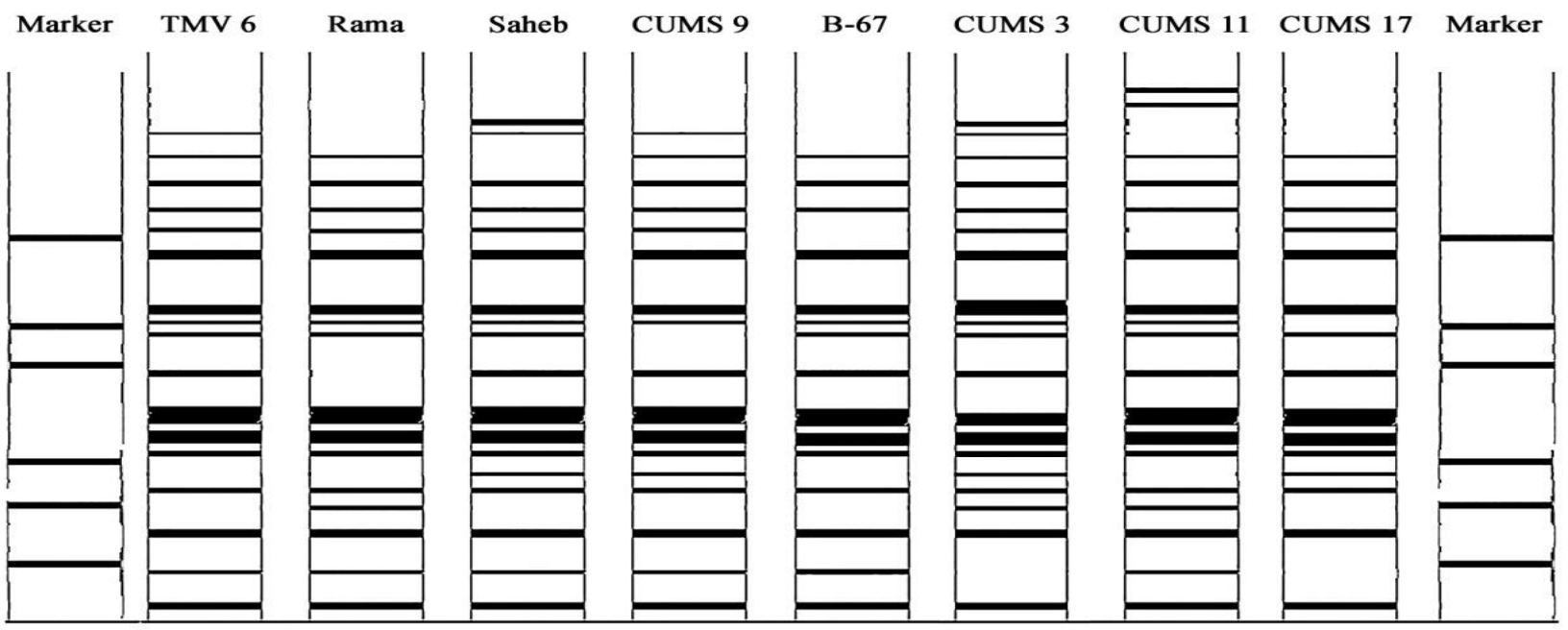

Marker

Figure 1 Zymogram for SDS-PAGE banding pattern of ten sesame cultivars with markers

involving sesame mutants and their parents. The heaviest band at the top of the gel with molecular weight of $125.59 \mathrm{KDa}$ was marked as one (1), the lightest polypeptide was the $22^{\text {nd }}$ band of 12.19 KDa found at the bottom. All the other polypeptides found in between these two bands had molecular weights ranging in between 125.59 KDa and 12.19 KDa. Sigma, Dalton Mark VI gave six marker bands of molecular weights $66 \mathrm{KDa}, 45 \mathrm{KDa}$, $34.7 \mathrm{KDa}, 24 \mathrm{KDa}, 18.4 \mathrm{KDa}$ and $14.4 \mathrm{KDa}$ respectively, distributed from top to bottom of the gel. Marker band of $45 \mathrm{KDa}$ divided all the bands almost at the mid-way. Ten bands appeared above $45 \mathrm{KDa}$ band and twelve below. Besides, variation in total number of bands was observed in different genotypes offering seed storage protein polymorphism of 59.1\%. A zymogram for ten genotypes is given in Figure 1, along with marker bands. Seven protein bands, namely, band no. 6, 7, 9, 10, 14, 15, 18, 20 and 22, out of these twenty two bands were monomorphic. The other thirteen bands, namely, band no. 1, 2, 3, 4, 5, 8, 11, 12, 13, 16, 17, 19 and 21 exhibited polymorphism. The detail of the polymorphic bands is given in Table 2 .

Table 2 Detail of polymorphic bands

\begin{tabular}{cccccc|}
$\begin{array}{c}\text { Band } \\
\text { Position }\end{array}$ & $\begin{array}{c}\text { Molecular } \\
\text { weight } \\
(\mathrm{KDa})\end{array}$ & $\begin{array}{c}\text { Band } \\
\text { Position }\end{array}$ & $\begin{array}{c}\text { Molecular } \\
\text { weight } \\
\text { (KDa) }\end{array}$ & $\begin{array}{c}\text { Band } \\
\text { Position }\end{array}$ & $\begin{array}{c}\text { Molecular } \\
\text { weight } \\
(\mathrm{KDa})\end{array}$ \\
\hline 1 & 125.59 & 8 & 68.05 & 17 & 22.37 \\
\hline 2 & 116.32 & 11 & 45.46 & 19 & 18.14 \\
\hline 3 & 107.20 & 12 & 42.25 & 21 & 14.07 \\
\cline { 1 - 3 } 4 & 102.39 & 13 & 33.23 & & \\
\cline { 1 - 3 } 5 & 93.40 & 16 & 24.96 & & \\
\hline
\end{tabular}


3.1 Protein banding pattern for agro-ecological zone of adoption

The distribution of polymorphic protein bands in all the cultivars is presented in Table 3. The distribution pattern revealed the presence or absence of some specific polypeptides or protein bands which were associated with specific agro-ecology as explained here. It is evident from Table 3 that polypeptides of 68.05 KDa, 42.25 KDa, 33.23 KDa \& 24.96 KDa were present in all the cultivars except those from Haryana, Rajasthan and West Bengal. Absence of these bands can be related to the specific agro-ecology of these three states which was very different from all the other states (Table 1). While humid coastal agro-ecology of West Bengal might be associated with the unique presence of 45.46 KDa polypeptide in all the cultivars from this state, the arid agro-ecology of Haryana and Rajasthan was convincingly linked with the unique presence of protein bands of $116.32 \mathrm{KDa}$ and 107.20 KDa in the representative cultivars. The banding pattern also revealed that, polypeptide of $93.40 \mathrm{KDa}$ (Band no. 5) can be considered as the linking polypeptide between arid and semi-arid agro-ecology, while that of $14.07 \mathrm{KDa}$ (Band no. 21) must be the link between semi-arid, sub-humid \& coastal agro-ecology. Presence of protein band of $68.05 \mathrm{KDa}$ (Band no. 8) was a typical to the cultivars from those states which covered a range of agroecological zones rather than a single one.

\section{2. Protein banding pattern for seed coat colour}

In case of seed coat colours, unique protein banding pattern was revealed as represented in Table 4. Protein bands of $42.25 \mathrm{KDa}$, 33.23 KDa \& $24.96 \mathrm{KDa}$ (Band no. 12, 13, 16 respectively) was present uniformly in the white seeded cultivars, while presence of polypeptides of $68.05 \mathrm{KDa} \& 45.46 \mathrm{KDa}$ (Band no. 8 \& 11 respectively) additional to band no. 12,13,16 was found for pale yellow seed coat. Polypeptide of $93.40 \mathrm{KDa}$ was most probably related to darker seed coats, namely, brown and deep brown (Band no. 5). All the protein bands except that of $68.05 \mathrm{KDa}$, specific to different seed coat colours were present in the cultivars with mixed seed coat colours, ranging from pale yellow to brown to deep brown, which confirms the association specific polypeptides to specific seed coats as discussed. Absence of 68.05 KDa protein must had been compensated by the specific presence of polypeptide of $18.14 \mathrm{KDa}$ in these mixed coloured cultivars only. It can be concluded from Table 4 that brown and dark brown seed coat were probably the results of complex interplay of reaction due to presence and absence of protein bands of 68.05 $\mathrm{KDa}$ and $24.96 \mathrm{KDa}$ along with other three bands of $42.25 \mathrm{KDa}$, $33.23 \mathrm{KDa} \& 24.96 \mathrm{KDa}$.
Table 3 Distribution of protein polymorphic bands for agro-ecologica zone of adoption

\begin{tabular}{|lccc|}
\hline $\begin{array}{c}\text { Agro-ecological zone } \\
\text { of adoption }\end{array}$ & State & Band position $^{1}$ \\
\hline Sub-humid, Coastal & Odisha & $8, \quad 12,13,16,21$ \\
\hline Semi-arid, sub-humid & $\begin{array}{c}\text { Madhya } \\
\text { Pradesh }\end{array}$ & $5,8,11,12,13,16,21$ \\
\hline Arid, Semi-arid & Karnataka & $8, \quad 12,13,16,21$ \\
\hline Semi-arid, Coastal & Tamil Nadu & $4, \quad 8, \quad 12,13,16,21$ \\
\hline $\begin{array}{l}\text { Arid, Semi-arid, } \\
\text { Coastal }\end{array}$ & Gujarat & $5,8,11,12,13,16$ \\
\hline Arid & $\begin{array}{c}\text { Haryana, } \\
\text { Rajasthan }\end{array}$ & $2,3, \quad 5, \quad 12,3,16$ \\
\hline $\begin{array}{l}\text { Humid-per humid, } \\
\text { Coastal }\end{array}$ & Bengal & \multicolumn{2}{c|}{11} \\
\hline
\end{tabular}

${ }^{1}$ Positions of those polymorphic bands which were uniformly present in all genotypes specific to a particular zone of adoption and seed coat colour. The molecular weights of the bands can be found from Table 2 .

Table 4 Distribution of protein polymorphic bands for seed coat colour

$\begin{array}{ll}\text { Seed coat colour } & \text { Band position }^{1}\end{array}$

\begin{tabular}{|c|c|}
\hline White & $12,13,16$ \\
\hline Pale yellow & $8,11,12,13,16$ \\
\hline Brown & 16 \\
\hline Dark brown & $5,8,11,12,13$ \\
\hline Mixed & $5, \quad 11,12,13,16,19$ \\
\hline
\end{tabular}

Positions of those polymorphic bands which were uniformly present in all genotypes specific to a particular seed coat colour. The molecular weights of the bands can be found from Table 2 .

\section{3. Dendrogram and clustering pattern}

The dendrogram (Figure 2) computed from the polymorphic banding pattern, revealed complete linkage between genotypes at specific distances. It revealed two clusters, as marked by the parentheses. The cluster with larger number of cultivars was divided into five sub-clusters marked by straight lines. Genotypes within same cluster shared high degree of similarity with each other than genotypes in different clusters. Highest similarity coefficient of 1.0 was observed between TKG-22 and TMV-6, belonging to two distinctly different agro-ecological zones (Table 1) and least similarity (0.73) was observed between OSC -207 and CUMS 17 also from two states with very different agro-ecology (Table 1). The clustering pattern revealed no specific correlation of protein similarity of the cultivars, neither to the cultivars' zone of adoption, as reported earlier by Dar et al. (2014), nor with their seed coat colour. This outcome is of common occurrence with nucleic acids markers also (Pham et al., 2009; Wei et al., 2008). 


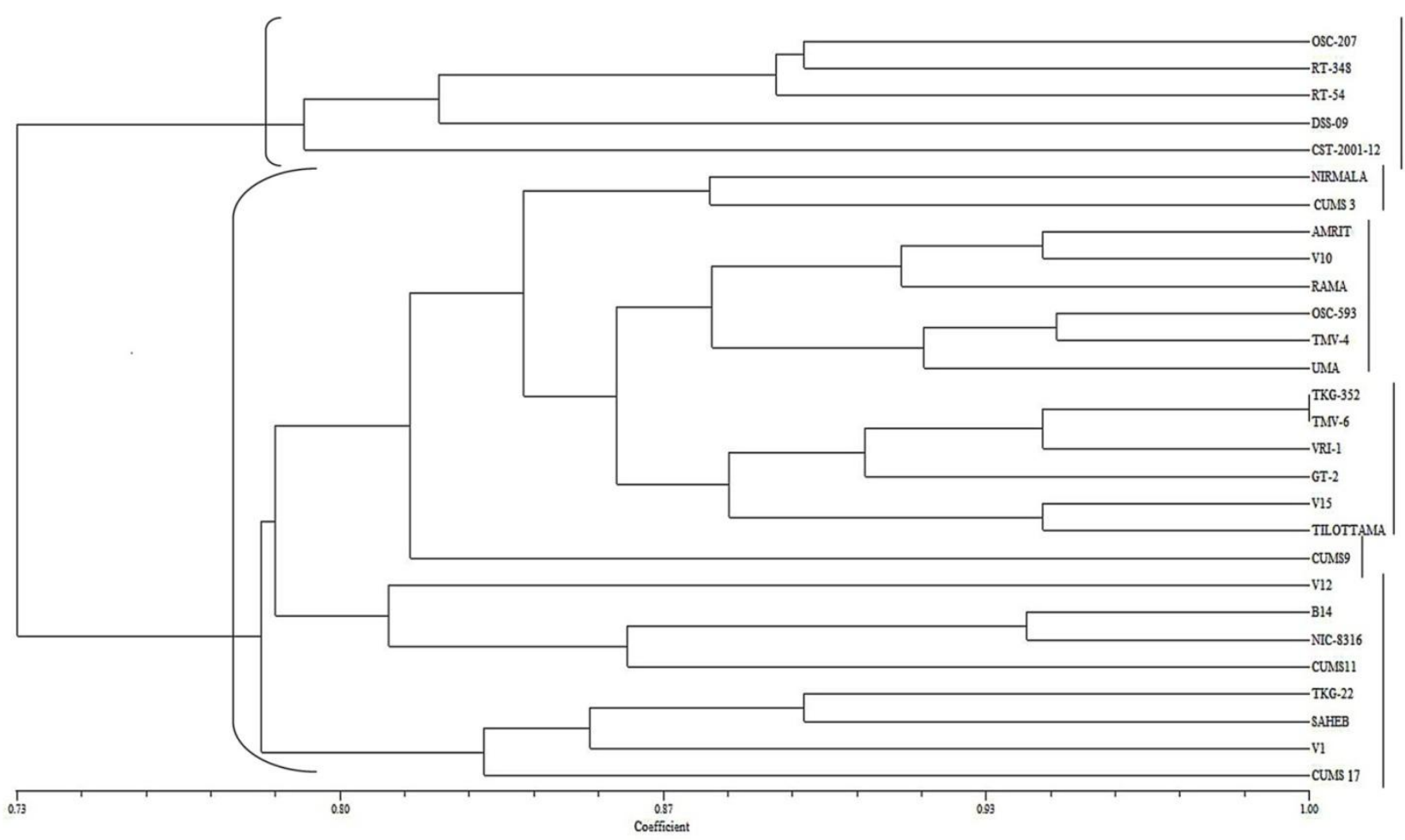

Figure 2 Dendrogram of twenty eight sesame cultivars based on soluble seed storage protein polymorphism

\section{Discussion and conclusions}

Human interference played a great role in spreading crop cultivars to different regions, which probably led to lack of correlation in clustering of cultivars with zone of adoption (Stankiewicz et al., 2001). Moreover, it is well known that a single agro-ecology can be sub-divided into a number of agro-climatic zones and sub-agro climatic zones which leads to a range of genotype and environmental interaction (GE) within a single agro-ecology. In India, fifteen agro-ecological regions have been sub-divided into as many as 127 agro-climatic regions (vikaspedia.in). In the present study, similar to findings of Akbar et al. (2012), specific polypeptides were obtained related to specific agro-ecology, like that of West Bengal (humid), Haryana (arid) and Rajasthan (arid), but it was not possible to identify unique protein bands specific to those cultivars which were originated in the states with mixed agro-ecology.

Hence to draw any definite inference on divergence, phylogeny and pattern of distribution of sesame populations in Indian subcontinental context, more genotypic representation from different agro-climatic regions are required. Cultivar specific polypeptides and identifying specific protein fractions is also a potent field for a more precise outcome. Seed coat colour in sesame is linked to other important biochemical traits (Kanu, 2011; Zhang et al.,
2013). Assessment of such traits, like, oil content, antioxidant content, free fatty acid content \& many others, and linking such traits to seed coat colour specific - polypeptides will definitely help in screening superior and diverse sesame genotypes for crop improvement programs more precisely.

\section{References}

Akbar F, Yousaf N, Ashiq Rabbani M, Khan Shinwari Z, Shahid Masood M (2012) Study of total seed proteins pattern of sesame (Sesamum Indicum L.) landraces via sodium dodecyl sulfate polyacrylamide gel elecrophoresis (SDS-PAGE). Pakistan Journal of Botany 44:2009-2014.

Akhila H, Beevy S (2011) Morphological and seed protein characterization of the cultivated and the wild taxa of Sesamum L. (pedaliaceae). Plant Systematics and Evolution 293: 65-70.

Alvarez JB, Moral A, Martin LM (2006) Polymorphism and genetic diversity for the seed storage proteins in Spanish cultivated einkorn wheat (Triticum monococcum L. ssp. monococcum). Genetic Resources and Crop Evolution 53 :106167.

Dar AA, Roy Choudhury A, Arumugam N (2014) A study on seed protein profile of Indian cultivars of Sesamum indicum L. International Journal of Current Biotechnology 2:10-17. 
Das A, Pandey S, Dasgupta T (2013) Genotype-environment interaction in sesame (Sesamum indicum L.) genotypes and identification of stable types. In: Proceedings of International conference on Agri \& Animal Sciences, 8-9 July 2013; Colombo, Sri Lanka. International Center for Research and Development, Pp. $43-72$.

FAOSTAT (2016) Food and Agriculture Organization of the United Nations [online] Available at: http://faostat.fao.org/site/339/default.aspx, accessed on December 12, 2016.

Ghafoor A, Ahmad Z, Qureshi A, Bashir M (2002) Genetic relationship in Vigna mungo (L.) Hepper and V. radiata (L.) R. Wilczek based on morphological traits and SDS-PAGE. Euphytica 123:367-78.

http://vikaspedia.in/InDG Available at: http://vikaspedia.in/agriculture/crop-production/weatherinformation/agro-climatic-zones-in-india, accessed on December 12,2016

Huber-Morath A, Phlomis L (1982) Flora of Turkey and East Aegean Island. In: Davis PH (Ed.), Edinburgh University Press, Edinburgh, Pp.102-126.

Jha SS, Ohri D (2002) Comparative study of seed protein profiles in the genus Pisum. Biologia Plantarum 45:529-32.

Kanu PJ (2011) Biochemical analysis of black and white sesame seeds from China. American Journal of biochemistry and Molecular Biology 1:145-57.

Khurshid H, Rabbani MA (2012) Comparison of electrophoretic protein profiles from seed of different oilseed Brassica cultivars. Journal of Public Health and Biological Sciences 1:36-42.

Laemmli UK (1970) Cleavage of structural proteins during the assembly of the head of bacteriophage T4. Nature 227:680-685.

Lowry OH, Rosebrough NJ, Farr AL, Randall RJ (1953) Protein measurement with the folin-phenols reagent. Journal of Biological Chemistry 193:265-75.

Pabby AB, Rockman MV (2013) The many faces of pleiotropy. Trends in Genetics 29: 67-73.

Pham TD, Bui TM, Werlemark G, Bui TC, Merker A, Carlsson AS (2009) A study of genetic diversity of sesame (Sesamum indicum L.) in Vietnam and Cambodia estimated by RAPD markers. Genetic Resources and Crop Evolution 56:679-690.

Rohlf FJ (2005) Numerical Taxonomy and Multivariate Analysis System, Version 2.20, Applied Biostatistics, New York.

Singharaj S, Onsaard E (2015) Production and characteristic of sesame proteins. Journal of Food Science and Agricultural Technology 1:188-192.

Stankiewicz M, Gadanski G, Gawronski SW (2001) Genetic variation and phylogenetic relationships of triazine resistant and triazine susceptible biotypes of Solanum nigrum analysis using RAPD markers. Weed Research 41: 287-300.

Wang Z, Liao BY, Zhang J (2010) Genomic patterns of pleiotropy and the evolution of complexity. Proceedings of The National academy of Sciences 107:18034-18039.

Wei LB, Zhang HY, Zheng YZ, Guo WZ, Zhang TZ (2008) Development and utilization of EST-derived microsatellites in sesame (Sesamum indicum L.). Acta Agronomica Sinica 34: 2077-2084.

Zhang H, Hongmei M, Libin W, chun L, Zhao R, Wang (2013) Genetic analysis and qtl mapping of seed coat color in sesame (Sesamum indicum L.). PLoS ONE 8: e63898. doi:10.1371/journal.pone.0063898. 